Proceedings

\title{
Quantitative Microbial Risk Assessment (QMRA) of Campylobacter for Roof-Harvested Rainwater Domestic Use ${ }^{+}$
}

\author{
Jálvaro da Hora ${ }^{1}$, Eduardo Borges Cohim ${ }^{2, *}$, Samuel Sipert ${ }^{2}$ and Adriano Leão ${ }^{2}$ \\ 1 Federal Institute of Education, Science and Technology of Bahia, Emidio dos Santos Street, \\ Salvador-BA 40301-015, Brazil; jalvaro.hora@gmail.com \\ 2 Department of Technology, State University of Feira de Santana, Transnordestina Avenue, \\ Feira de Santana-BA 44036-900, Brazil; ssipert@hotmail.com (S.S.); adrianoleaoeng@outlook.com (A.L.) \\ * Correspondence: edcohim@gmail.com \\ + Presented at the 2nd International Electronic Conference on Water Sciences, 16-30 November 2017; \\ Available online: http://sciforum.net/conference/ecws-2.
}

Published: 16 November 2017

\begin{abstract}
The present study evaluated the microbiological risk for roof-harvested rainwater (RHRW), with Campylobacter as the pathogenic microorganism of reference, using a Quantitative Microbial Risk Assessment (QMRA). QMRA has been widely used as an alternative method for epidemiological assessment of human exposure to microorganisms that can cause diseases, through a four-step process: hazard identification, exposure assessment, dose-response assessment, and risk characterization. The results presented drinking as the water use with the highest median value for microbiological risk, with $3.4 \times 10^{-4}$ disability-adjusted life years (DALYs) per person per year (pppy), and bathing, food washing, hose irrigation and toilet flushing with median values of $6.5 \times$ $10^{-7}, 4.0 \times 10^{-7}, 2.1 \times 10^{-7}$ and $1.4 \times 10^{-7}$ DALYs pppy, respectively. Therefore, drinking would be the only water use that would require preliminary treatment for its safe use, considering the acceptable risk standards set by the World Health Organization for drinking water. However, with the adoption of a sanitary barrier and a simple point-of-use treatment system, it was observed that drinking rainwater would have a median microbiological risk of $2 \times 10^{-6}$ DALYs pppy, enough to meet the safety criteria considering developing countries.
\end{abstract}

Keywords: risk assessment; rainwater harvesting; drinking water

\section{Introduction}

Roof-harvested rainwater (RHRW) has been increasingly adopted as an alternative water supply for domestic uses, including drinking, especially in rural areas of developing countries [1,2]. In Brazil, for example, since 2003, more than 588,000 cisterns have been built in order to provide safe water for rural communities in the Northeast that do not have access to centralized water supply systems [3].

However, there is an ongoing debate regarding whether RHRW should be used as drinking water [4]. Some epidemiological studies suggest that consumption of untreated rainwater does not contribute to the incidence of disease in a community [5,6], while others have documented contamination in stored rainwater, posing a definitive public health risk if consumed without treatment [7-9].

The World Health Organization (WHO) has created drinking water guidelines to ensure the provision of high-quality water around the world [10]. In order to satisfy these limits, especially regarding microbiological contaminants, chlorine has been applied in rainwater cisterns as a 
disinfection method in Brazil, raising the concern about consumption of chlorination by-products in drinking water, which are associated with cancer in humans [11-15].

In this context, there is an increasing need to assess human health risks associated with RHRW exposure, especially in developing countries, where its use is becoming more widespread. The Quantitative Microbiological Risk Assessment (QMRA) approach applies risk assessment principles to estimate the effects of human exposure to infectious microorganisms in different scenarios [16], and has been used worldwide to establish guidelines and recommendations for water quality (WHO, 2011), with many studies focusing on rainwater $[7,8,17]$.

This study aims to assess the human health risks from untreated RHRW domestic use through the QMRA method, and analyze the overall impact for the adoption of a sanitary barrier and a pointof-use device to improve rainwater quality in RHRW systems.

\section{Methods}

\subsection{Literature Review}

Data collection regarding pathogen concentration in RHRW was conducted by searching webbased databases and governmental agencies' websites for key words such as 'roof-harvested rainwater', 'pathogens', 'health', and 'risk'. The literature review did not have any geographical restrictions, although English-language papers were the major source of information.

\subsection{Quantitative Microbial Risk Assessment (QMRA)}

A QMRA framework was applied to assess the potential microbial health risks associated with the following proposed uses for RHRW: bathing, food washing, hose irrigation, toilet flushing and drinking. Where possible, input data have been represented as probability distributions rather than point-estimates in order to reduce uncertainty. A Monte Carlo sampling composed of 10,000 iterations was used for simulations using the software @Risk version 4.5 Professional edition (Palisade Corporation 2002).

Results for health impacts were quantified using disability-adjusted life years (DALYs). DALYs are a summary measure of a population's health, allowing comparison of effects across a wide range of health outcomes. The measure combines years of life lost (YLL) as a result of premature mortality, with years lived with a disability (YLD) standardized using severity weights with a range from 0 (perfect health) to 1 (dead) [18-21].

The QMRA addresses a quantitative approach through simulation techniques and scenario modeling, following a four-step process [16], divided into hazard identification and characterization, exposure assessment, dose-response evaluation, and risk characterization.

\subsection{Hazard Identification}

The main source of waterborne pathogens in RHRW in Brazil is likely to be from faecal droppings from birds and other animals with roof habits. Other possible routes from the catchment surface, according to Sanchez et al. [22], include deposits of dirt, lichens and mosses, fungus or fallen vegetable material from the surrounding trees.

From the literature review, the most commonly found microorganisms in stored RHRW are Campylobacter, Cryptosporidium, Salmonella, Giardia, Escherichia coli and Enterococcus, all major etiological agents of gastroenteritis worldwide [23-27].

Campylobacter ssp. is linked with zoonosis in birds and animals that inhabit or transit on the roofs [28,29], being one of the most important causes of acute gastroenteritis worldwide [10]. In addition, it has been isolated from rainwater supplies (Table 1) and implicated in illness from rainwater supplies used for drinking water [30]. So, for this study, Campylobacter ssp. was used as the pathogen of reference for the QMRA. 
Table 1. Presence of Campylobacter in stored roof-harvested rainwater (RHRW) from different sources.

\begin{tabular}{cccc}
\hline Samples Tested & Positive Samples & Frequency of Contamination (\%) & Concentration (MPN/L) \\
\hline 27 & 11 & $40.7 \%$ & n.a. [31] \\
10 & 1 & $10.0 \%$ & $<3-43[32]$ \\
27 & 10 & $37.0 \%$ & n.a. [33] \\
100 & 20 & $20.0 \%$ & n.a. [7] \\
115 & 0 & $0.0 \%$ & n.a. [34] \\
24 & 5 & $20.8 \%$ & $5-100[35]$ \\
17 & 2 & $11.8 \%$ & n.a. [36] \\
24 & 9 & $37.5 \%$ & $<0.6-5.6[37]$ \\
32 & 3 & $9.4 \%$ & $26-240[38]$ \\
100 & 3 & $3.0 \%$ & $0-0.056[20]$ \\
\hline
\end{tabular}

\subsection{Exposure Assessment}

A literature review has been conducted to gather data regarding exposure routes for Campylobacter infection and intake volumes associated with each of the proposed domestic uses for RHRW. Infection routes may include liquid ingestion due to drinking, accidental liquid ingestion due to hose irrigation and food washing, aerosol ingestion due to showering, and direct contact with water.

Volume ingested, and exposure duration and frequency for drinking were taken from the publication titled "Exposure Factors Handbook" from the American Environmental Agency [39]. Parameters of exposure for hose irrigation and food washing were taken from Ahmed et al. [7]. Data for toilet flushing were taken from Ashbolt et al. [40] and Fewtrell et al. [20]. Finally, data from Cohim et al. [17] were used for exposure assessment for bathing.

The input data used for exposure assessment are summarized in Table 2.

Table 2. Risk input values.

\begin{tabular}{lcccccc}
\hline \multicolumn{1}{c}{ Input } & Distribution & Mean & Median & Mode & $\begin{array}{c}\text { Standard } \\
\text { Deviation }\end{array}$ & Range \\
\hline Campylobacter concentration (mL) & Lognormal & - & 5.6 & - & - & $0-240$ \\
\hline $\begin{array}{l}\text { Volume ingested (mL) } \\
\quad \text { Drinking }\end{array}$ & Triangular & - & 2500 & - & - & $1400-3600$ \\
Bathing (mL/min) & Normal & 0.5 & - & - & 0.2 & - \\
Food washing & Normal & 0.5 & - & - & 0.1 & - \\
Hose irrigation & Lognormal & 1.0 & - & - & 0.1 & - \\
Toilet flushing & Triangular & - & - & 0.1 & - & $0.01-0.5$ \\
\hline Exposure duration (minutes) & & & & & & \\
Bathing & Lognormal & - & 3 & - & - & $0.9-44$ \\
\hline Frequency of use (\#/day) & & & & & - & $0.1-5$ \\
Bathing & Lognormal & 0.9 & - & - & - & $2.0-6$ \\
Food washing & Triangular & - & 4 & - & - & $1.0-7$ \\
Hose irrigation & Lognormal & - & 3 & - & - & $2.0-6$ \\
Toilet flushing & Triangular & - & 4 & - & - & \\
\hline
\end{tabular}

\subsection{Dose-Response Assessment}

Pathogen ingestion was calculated using Equation (1), based on the probability distributions for parameters from the exposure assessment. The equation used is expressed as:

$$
\mathrm{d}=\mathrm{N} \times \text { Ving, }
$$

where

$\mathrm{d}=$ Dose of pathogens ingested in one exposure $\left(\mathrm{MPN} \cdot \mathrm{day}^{-1}\right)$;

$\mathrm{N}=$ Pathogen concentration in RHRW $\left(\mathrm{MPN} \cdot \mathrm{mL}^{-1}\right)$; 


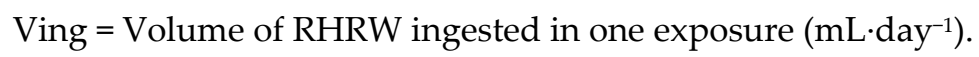

The mathematical model used to relate the ingested dose with its outcome varies depending on the pathogen considered. A dose-response $\beta$-poisson model for Campylobacter ssp. has been developed by Medema et al. [41] and it is presented in Equation (2).

$$
\operatorname{Pinf}=1-\left[1+\left(\mathrm{d} / \mathrm{N}_{50}\right)\right] /\left[2^{1 / \alpha}-1\right]^{-\alpha},
$$

where

Pinf = probability of infection for one exposure;

$\mathrm{N}_{50}=$ microbial dose eliciting $50 \%$ infections in the exposed population $=896$ [41];

$\alpha=$ slope parameter $=0.145[41]$.

\subsection{Risk Characterization}

Risk characterization encompasses all the previous steps (hazard characterization, doseresponse assessment and exposure-assessment) to determine the probability of infection and illness. The annual probability of infection is calculated using Equation (3):

$$
\mathrm{Pt}=1-(1-\mathrm{Pinf})^{\mathrm{t}},
$$

where

$\mathrm{Pt}=$ annual probability of infection;

Pinf = probability of infection for one exposure;

$\mathrm{t}=$ number of exposures in one year.

To estimate the annual probability of disease, i.e., the number of disease cases per person per year, it has been assumed that 70\% of infections result in illness [42], as seen in Equation (4).

$$
\mathrm{Pd}=\mathrm{K} \times \mathrm{Pt},
$$

where

$\mathrm{Pd}=$ annual probability of illness;

$\mathrm{K}=$ disease/infection ratio $=0.7[42]$.

Based on the probability of illness, the results of disease cases for each use were transformed in DALY loss per person per year (pppy). We have adopted a value of DALY loss per disease case of 4.6 $\times 10^{-3}$ for Campylobacter [42].

The distributions and @Risk input values used in the QMRA are shown in Table 2.

\section{Results and Discussion}

The risks for the proposed domestic uses for RHRW are summarized in Table 3, both in probability of illness and DALYs pppy.

Table 3. Median values of annual risk for different RHRW uses.

\begin{tabular}{ccc}
\hline Proposed Water Use & Probability of Illness & DALYs pppy \\
\hline Drinking & $7.39 \times 10^{-2}$ & $3.40 \times 10^{-4}$ \\
Bathing & $1.41 \times 10^{-4}$ & $6.50 \times 10^{-7}$ \\
Food washing & $8.70 \times 10^{-5}$ & $4.00 \times 10^{-7}$ \\
Hose irrigation & $4.57 \times 10^{-5}$ & $2.10 \times 10^{-7}$ \\
Toilet flushing & $3.04 \times 10^{-5}$ & $1.40 \times 10^{-7}$ \\
\hline
\end{tabular}

As expected, drinking untreated RHRW had the highest microbiological estimated risk, with a value of $3.40 \times 10^{-4}$ DALYs pppy. All the other uses (bathing, food washing, hose irrigation and toilet flushing) had results in the order magnitude of $10^{-7}$. Therefore, only drinking untreated RHRW would not satisfy the microbiological risk limit suggested by the WHO for drinking water of $10^{-6}$ DALYs pppy.

However, there has been a discussion on whether this limit would be the most appropriate, especially for developing countries [43]. The WHO itself admits that this target may not be achievable 
or realistic in some locations and circumstances in the near term, where the overall burden of disease is high for multiple exposure routes (water, food, air, etc.). In these cases, setting this limit from waterborne exposure alone would not have a big impact on the overall disease burden, and more contextualized values could be established [10]. For Brazil, for example, the risk of drinking untreated RHRW is significantly lower than $1.8 \times 10^{-2}$ DALYs pppy, which represents the DALY loss from tobacco-related diseases in 2015 [44].

Therefore, to evaluate the severity of consequences from the estimated risks, we adopted the classification proposed by Westrell et al. [45] (Table 4), based on the increase of endemic disease in the community caused by RHRW use. Studies estimate a median value of three to five episodes of diarrhoea per child per year for children under 5 years of age in developing countries [46-51]. We adopted a median value of four episodes of diarrhoea per person per year for Brazil.

Table 4. Suggested definitions of severity of consequences of hazards based on an increase of endemic disease in the community [45].

\begin{tabular}{ll}
\hline Item & Definition \\
\hline \multirow{2}{*}{ Catastrophic } & Major increase in diarrhoeal diseases $>25 \%$ or $>5 \%$ increase in more severe diseases or a \\
& large community outbreak (100 cases) or death \\
Major & Increase in more severe diseases $(0.1-5 \%)$ or a large increase in diarrhoeal diseases $(5-25 \%)$ \\
Moderate & Increase in diarrhoeal diseases $(1-5 \%)$ \\
Minor & Slight increase in diarrhoeal diseases $(0.1-1 \%)$ \\
Insignificant & No increase in disease incidence $(<0.1 \%)$ \\
\hline
\end{tabular}

Based on the increase of disease cases (Table 5), drinking RHRW without any treatment would represent a $1.85 \%$ increase, with a hazard classified as 'moderate' by Westrell et al. [45].

Table 5. Severity of consequences for the proposed RHRW uses.

\begin{tabular}{cccc}
\hline Proposed Water Use & Probability of Illness & Increase of Disease Cases & Hazard \\
\hline Drinking & $7.39 \times 10^{-2}$ & $1.85 \%$ & Moderate \\
Bathing & $1.41 \times 10^{-4}$ & $0.004 \%$ & Insignificant \\
Food washing & $8.70 \times 10^{-5}$ & $0.002 \%$ & Insignificant \\
Hose irrigation & $4.57 \times 10^{-5}$ & $0.001 \%$ & Insignificant \\
Toilet flushing & $3.04 \times 10^{-5}$ & $0.001 \%$ & Insignificant \\
\hline
\end{tabular}

Once the health risks for the domestic use of untreated RHRW have been estimated, the adoption of measures to increase the quality of rainwater was tested. The adoption of a rainwater first-flush diverter device for the catchment system, and the use of a ceramic water filter, a simple point-of-use treatment for drinking water, were considered given their good public acceptance and due to the fact that they do not require high maintenance for their operation.

Many studies have evaluated the efficiency of rainwater first-flush diverter devices (Table 6), and ceramic water filters (Table 7), showing effective contaminant removal and water quality improvement, proving their potential as measures to improve RHRW quality. Based on the literature, we have estimated the pathogen removal efficiency for Campylobacter of $96 \%$ and $93 \%$, for rainwater fist-flush diverters and ceramic water filters, respectively.

Health risk values were then calculated and the hazards were characterized based on the increase of disease cases, considering the adoption of each sanitary barrier and, for drinking water, considering both sanitary barriers (Table 8).

Results show that the estimated health risks for drinking RHRW would drop from $3.4 \times 10^{-4}$ to $2.92 \times 10^{-5}$ DALYs and $3.5 \times 10^{-5}$ DALYs pppy by using the rainwater first-flush diverter and ceramic water filter, respectively. When considered together, it was possible to achieve a risk reduction from $3.4 \times 10^{-4}$ to $2 \times 10^{-6}$ DALYs pppy, a significant gain in safety, almost satisfying the WHO guidelines for drinking water, with no need for disinfection through chlorination. 
Table 6. Pathogen removal efficiency for rainwater first-flush systems.

\begin{tabular}{cc}
\hline Pathogen & Removal Efficiency \\
\hline Total coliforms & $95.5 \%[52]$ \\
& $96.5 \%[53]$ \\
& $96.5 \%[54]$ \\
\hline Thermostable coliforms & $100 \%[55]$ \\
\hline E. coli & $80 \%[56]$ \\
& $100 \%[54]$ \\
& $100 \%[53]$ \\
\hline Heterotrophic bacteria & $90 \%[57]$ \\
\hline Salmonella & $94.39 \%[52]$ \\
\hline
\end{tabular}

Table 7. Pathogen removal efficiency for ceramic water filters.

\begin{tabular}{cc}
\hline Pathogen & Removal Efficiency \\
\hline & $97.8 \%[58]$ \\
E coli & $85 \%[59]$ \\
& $99 \%[60]$ \\
\hline Vibrio spp. & $100 \%[59]$ \\
\hline Shigella spp. & $93 \%[59]$ \\
\hline Salmonella & $86 \%[59]$ \\
\hline
\end{tabular}

Table 8. Median values of annual risk considering the adoption of sanitary barriers.

\begin{tabular}{|c|c|c|c|c|c|}
\hline $\begin{array}{c}\text { Proposed Water } \\
\text { Use }\end{array}$ & Sanitary Barrier & $\begin{array}{c}\text { Probability of } \\
\text { Illness }\end{array}$ & DALYs & $\begin{array}{c}\text { Increase of } \\
\text { Disease }\end{array}$ & Hazard \\
\hline \multirow{3}{*}{ Drinking } & First-flush diverter & $6.30 \times 10^{-3}$ & $2.92 \times 10^{-5}$ & $0.16 \%$ & Minor \\
\hline & Ceramic filter & $7.61 \times 10^{-3}$ & $3.50 \times 10^{-5}$ & $0.19 \%$ & Minor \\
\hline & Both & $4.35 \times 10^{-4}$ & $2.00 \times 10^{-6}$ & $0.01 \%$ & Insignificant \\
\hline Bathing & First-flush diverter & $7.83 \times 10^{-6}$ & $3.60 \times 10^{-8}$ & $0.000 \%$ & Insignificant \\
\hline Food washing & First-flush diverter & $5.00 \times 10^{-6}$ & $2.30 \times 10^{-8}$ & $0.000 \%$ & Insignificant \\
\hline Hose irrigation & First-flush diverter & $2.61 \times 10^{-6}$ & $1.20 \times 10^{-8}$ & $0.000 \%$ & Insignificant \\
\hline Toilet flushing & First-flush diverter & $1.74 \times 10^{-6}$ & $8.00 \times 10^{-9}$ & $0.000 \%$ & Insignificant \\
\hline
\end{tabular}

\section{Conclusions}

Based on a literature survey, we conducted a QMRA study on untreated RHRW use for domestic purposes. Our results indicated drinking RHRW as the only domestic water use that does not conform with the WHO guidelines for drinking water; even so, drinking untreated RHRW would only represent a $1.85 \%$ increase in disease cases in Brazil.

The adoption of simple sanitary barriers such as rainwater first-flush diverters and point-of-use treatment systems such as ceramic water filters, has proved to be sufficient to reduce the health risk for drinking untreated RHRW to levels that almost satisfy the WHO guidelines. Such results raise the discussion of adopting a tolerable risk for drinking water that respects regional characteristics, especially in developing countries, to the detriment of chlorination for residential rainwater catchment systems.

Author Contributions: Jálvaro da Hora and Eduardo Borges Cohim collected the data and conducted the Quantitative Microbiological Risk Analysis. Samuel Sipert and Adriano Leão also analyzed the results and contributed by writing the paper in English. The paper was originally written in Portuguese. All authors wrote the paper.

Conflicts of Interest: The authors declare no conflict of interest. 


\section{References}

1. Meera, V.; Ahammed, M.M. Water quality of rooftop rainwater harvesting systems: A review. J. Water Supply Res. Technol. Aqua 2006, 55, 257-268.

2. Amin, M.; Han, M. Roof-harvested rainwater for potable purposes: Application of solar collector disinfection (soco-dis). Water Res. 2009, 43, 5225-5235.

3. (ASA), A.d.S.B. Ações-P1mc. Available online: http://www.asabrasil.org.br/acoes/p1mc (accessed on 5 November 2016).

4. Kim, Y.; Dao, A.D.; Kim, M.; Nguyen, V.-A.; Han, M. Design and management of rainwater harvesting systems to control water quality for potable purposes in cu khe, vietnam. Water Sci. Technol. Water Supply 2017, 17, 452-460.

5. Rodrigo, S.; Sinclair, M.; Forbes, A.; Cunliffe, D.; Leder, K. Drinking rainwater: A double-blinded, randomized controlled study of water treatment filters and gastroenteritis incidence. Am. J. Public Health 2011, 101, 842-847.

6. Heyworth, J.S.; Glonek, G.; Maynard, E.; Baghurst, P.A.; Finlay-Jones, J. Consumption of untreated tank rainwater and gastroenteritis among young children in south australia. Int. J. Epidemiol. 2006, 35, 1051-1058.

7. Ahmed, W.; Vieritz, A.; Goonetilleke, A.; Gardner, T. Health risk from the use of roof-harvested rainwater in southeast queensland, australia, as potable or nonpotable water, determined using quantitative microbial risk assessment. Appl. Environ. Microbiol. 2010, 76, 7382-7391.

8. Lim, K.-Y.; Jiang, S.C. Reevaluation of health risk benchmark for sustainable water practice through risk analysis of rooftop-harvested rainwater. Water Res. 2013, 47, 7273-7286.

9. Lye, D.J. Rooftop runoff as a source of contamination: A review. Sci. Total Environ. 2009, 407, 5429-5434.

10. Organization, W.H. Guidelines for Drinking-Water Quality, 4 ed.; World Health Organization: Geneva, Switzerland, 2011; Volume 1.

11. Morris, R.D.; Audet, A.-M.; Angelillo, I.F.; Chalmers, T.C.; Mosteller, F. Chlorination, chlorination byproducts, and cancer: A meta-analysis. Am. J. Public Health 1992, 82, 955-963.

12. Tokmak, B.; Capar, G.; Dilek, F.B.; Yetis, U. Trihalomethanes and associated potential cancer risks in the water supply in ankara, turkey. Environ. Res. 2004, 96, 345-352.

13. Ashbolt, N.J. Risk analysis of drinking water microbial contamination versus disinfection by-products (dbps). Toxicology 2004, 198, 255-262.

14. Pentamwa, P.; Sukton, B.; Wongklom, T.; Pentamwa, S. Cancer risk assessment from trihalomethanes in community water supply at northeastern thailand. Int. J. Environ. Sci. Dev. 2013, 4, 538, doi:10.7763/IJESD.2013.V4.410.

15. Mishra, B.K.; Gupta, S.K.; Sinha, A. Human health risk analysis from disinfection by-products (dbps) in drinking and bathing water of some indian cities. J. Environ. Health Sci. Eng. 2014, 12, 73, doi:10.1186/2052336X-12-73.

16. Haas, C.N.; Rose, J.B.; Gerba, C.P. Quantitative Microbial Risk Assessment; John Wiley \& Sons: Hoboken, NJ, USA, 1999.

17. Cohim, E. É seguro usar água de chuva para banho? In Proceedings of the 7th Simpósio Brasileiro de Captação e Manejo de Água de Chuva, Caruaru, PE, Brazil, October 2009; Gnadlinger, J. \& Brito, L.T.L, Eds..

18. Murray, C.J.; Ezzati, M.; Flaxman, A.D.; Lim, S.; Lozano, R.; Michaud, C.; Naghavi, M.; Salomon, J.A.; Shibuya, K.; Vos, T. Gbd 2010: Design, definitions, and metrics. Lancet 2012, 380, 2063-2066.

19. Murray, C.J.; Vos, T.; Lozano, R.; Naghavi, M.; Flaxman, A.D.; Michaud, C.; Ezzati, M.; Shibuya, K.; Salomon, J.A.; Abdalla, S. Disability-adjusted life years (dalys) for 291 diseases and injuries in 21 regions, 1990-2010: A systematic analysis for the global burden of disease study 2010. Lancet 2012, 380, 2197-2223.

20. Fewtrell, L.; Kay, D. Quantitative microbial risk assessment with respect to campylobacter spp. In toilets flushed with harvested rainwater. Water Environ. J. 2007, 21, 275-280.

21. Organization, W.H. Who Methods and Data Sources for Global Burden of Disease Estimates 2000-2011; Department of Health Statistics and Information Systems: Geneva, Switzerland, 2013.

22. Sánchez, A.; Cohim, E.; Kalid, R. A review on physicochemical and microbiological contamination of roofharvested rainwater in urban areas. Sustain. Water Qual. Ecol. 2015, 6, 119-137.

23. Laine, J.; Huovinen, E.; Virtanen, M.; Snellman, M.; Lumio, J.; Ruutu, P.; Kujansuu, E.; Vuento, R.; Pitkänen, T.; Miettinen, I. An extensive gastroenteritis outbreak after drinking-water contamination by sewage effluent, finland. Epidemiol. Infect. 2011, 139, 1105-1113.

24. Fhogartaigh, C.N.; Dance, D. Bacterial gastroenteritis. Medicine 2013, 41, 693-699. 
25. Nielsen, H.L.; Ejlertsen, T.; Engberg, J.; Nielsen, H. High incidence of campylobacter concisus in gastroenteritis in north jutland, denmark: A population-based study. Clin. Microbiol. Infect. 2013, 19, 445-450.

26. Murphy, H.; Thomas, M.; Schmidt, P.; Medeiros, D.; McFadyen, S.; Pintar, K. Estimating the burden of acute gastrointestinal illness due to giardia, cryptosporidium, campylobacter, E. coli o157 and norovirus associated with private wells and small water systems in canada. Epidemiol. Infect. 2016, 144, 1355-1370.

27. Soller, J.A.; Eftim, S.; Wade, T.J.; Ichida, A.M.; Clancy, J.L.; Johnson, T.B.; Schwab, K.; Ramirez-Toro, G.; Nappier, S.; Ravenscroft, J.E. Use of quantitative microbial risk assessment to improve interpretation of a recreational water epidemiological study. Microb. Risk Anal. 2016, 1, 2-11.

28. Mohan, V. Faeco-prevalence of campylobacter jejuni in urban wild birds and pets in new zealand. $B M C$ Res. Notes 2015, 8, 1, doi:10.1186/1756-0500-8-1.

29. Hald, B.; Skov, M.N.; Nielsen, E.M.; Rahbek, C.; Madsen, J.J.; Wainø, M.; Chriél, M.; Nordentoft, S.; Baggesen, D.L.; Madsen, M. Campylobacter jejuni and Campylobacter coli in wild birds on danish livestock farms. Acta Vet. Scand. 2016, 58, 11, doi:10.1186/s13028-016-0192-9.

30. Eberhart-Phillips, J.; Walker, N.; Garrett, N.; Bell, D.; Sinclair, D.; Rainger, W.; Bates, M. Campylobacteriosis in new zealand: Results of a case-control study. J. Epidemiol. Community Health 1997, 51, 686-691.

31. Ahmed, W.; Huygens, F.; Goonetilleke, A.; Gardner, T. Real-time pcr detection of pathogenic microorganisms in roof-harvested rainwater in southeast queensland, australia. Appl. Environ. Microbiol. 2008, 74, 5490-5496.

32. Chapman, H.; Cartwright, T.; Huston, R.; Toole, J.O. Water quality and health risks from urban rainwater tanks. In Water Quality and Health Risks from Urban Rainwater Tanks; CRC for Water Quality and Treatment: Boca Raton, FL, USA, 2008.

33. Ahmed, W.; Vieritz, A.; Gardner, T.; Goonetilleke, A. Microbial risks from rainwater tanks in south east queensland. Water 2009, 36, 80-85.

34. Simmons, G.; Hope, V.; Lewis, G.; Whitmore, J.; Gao, W. Contamination of potable roof-collected rainwater in auckland, new zealand. Water Res. 2001, 35, 1518-1524.

35. Ahmed, W.; Sidhu, J.; Toze, S. Speciation and frequency of virulence genes of enterococcus spp. Isolated from rainwater tank samples in southeast queensland, australia. Environ. Sci. Technol. 2012, 46, 6843-6850.

36. Albrechtsen, H.-J. Microbiological investigations of rainwater and graywater collected for toilet flushing. Water Sci. Technol. 2002, 46, 311-316.

37. Savill, M.; Hudson, J.; Ball, A.; Klena, J.; Scholes, P.; Whyte, R.; McCormick, R.; Jankovic, D. Enumeration of campylobacter in new zealand recreational and drinking waters. J. Appl. Microbiol. 2001, 91, 38-46.

38. Schets, F.; Italiaander, R.; Van Den Berg, H.; de Roda Husman, A. Rainwater harvesting: Quality assessment and utilization in the netherlands. J. Water Health 2010, 8, 224-235.

39. EPA, U. Exposure Factors Handbook 2011 Edition (Final); EPA: Washington, DC, USA, 2011.

40. Ashbolt, N.; Petterson, S.; Stenstrom, T.; Schonning, C.; Westrell, T.; Ottoson, J. Microbial risk assessment (mra) tool. Urban Water Rep. 2005:7. Goteborg. Urban Water, Chalmers University of Technology: 64.

41. Medema, G.; Teunis, P.; Havelaar, A.; Haas, C. Assessment of the dose-response relationship of campylobacter jejuni. Int. J. Food Microbiol. 1996, 30, 101-111.

42. Mara, D. Water-and wastewater-related disease and infection risks: What is an appropriate value for the maximum tolerable additional burden of disease? J. Water Health 2011, 9, 217-224.

43. Mara, D.; Hamilton, A.; Sleigh, A.; Karavarsamis, N. Discussion Paper: Options for Updating the 2006 Who Guidelines; WHO, FAO, IDRC, IWMI: Geneva, Switzerland, 2010.

44. José, B.P.S.; Corrêa, R.A.; Malta, D.C.; Vma, P.; França, E.B.; Teixeira, R.A.; Camargos, P.A.M. Mortality and disability from tobacco-related diseases in brazil, 1990 to 2015. Rev. Brasileira Epidemiol. 2017, 20, 75-89.

45. Westrell, T.; Schönning, C.; Stenström, T.-A.; Ashbolt, N. Qmra (quantitative microbial risk assessment) and haccp (hazard analysis and critical control points) for management of pathogens in wastewater and sewage sludge treatment and reuse. Water Sci. Technol. 2004, 50, 23-30.

46. Cuevas, L.E.; González, E.S.; Veras, I.C.L.; da Luz, E.O.; Batista Filho, M.; Gurgel, R.Q. Incidência e fatores de risco de diarréia e infecções respiratórias agudas em comunidades urbanas de pernambuco, brasil incidence and risks factors for diarrhoea and acute respiratory infections in urban. Cad. Saúde Pública 1999, 15, 163-171.

47. Lima, A.; Moore, S.; Barboza, M., Jr.; Soares, A.; Schleupner, M.; Newman, R.; Sears, C.; Nataro, J.; Fedorko, D.; Wuhib, T. Persistent diarrhea signals a critical period of increased diarrhea burdens and nutritional shortfalls: A prospective cohort study among children in northeastern brazil. J. Infect. Dis. 2000, 181, 1643-1651. 
48. Moraes, L.R.S.; Cancio, J.A.; Cairncross, S.; Huttly, S. Impact of drainage and sewerage on diarrhoea in poor urban areas in salvador, brazil. Trans. R. Soc. Trop. Med. Hyg. 2003, 97, 153-158.

49. Kosek, M.; Bern, C.; Guerrant, R.L. The global burden of diarrhoeal disease, as estimated from studies published between 1992 and 2000. Bull. World Health Organ. 2003, 81, 197-204.

50. Vasconcelos, M.J.d.O.B.; Batista Filho, M. Doenças diarréicas em menores de cinco anos no estado de pernambuco\&58; prevalência e utilização de serviços de saúde diarrheal disease in children under five years of age in the state of pernambuco, brazil\&58; prevalence and utilization of health services. Rev. Brasileira Epidemiol. 2008, 11, 128-138.

51. Walker, C.L.F.; Perin, J.; Aryee, M.J.; Boschi-Pinto, C.; Black, R.E. Diarrhea incidence in low-and middleincome countries in 1990 and 2010: A systematic review. BMC Public Health 2012, 12, 220, doi:10.1186/14712458-12-220.

52. Souza, S.D.; Montenegro, S.; Santos, S.M.; Pessoa, S.G.; Nóbrega, R.L. Avaliação da qualidade da água e da eficácia de barreiras sanitárias em sistemas para aproveitamento de águas de chuva. Rev Bras Recur Hidr 2011, 16, 81-93.

53. De Lima, J.C.A.L. Avaliação do Desempenho de Dispositivo de Desvio das Primeiras Águas de Chuva Utilizado em Cisternas no Semiárido Pernambucano. Master's Thesis, Federal University of Pernambuco, Recife-PE, Brazil. 2012. Available online: http://repositorio.ufpe.br/handle/123456789/10628 (accessed on 20 January 2018).

54. Carvalho, J.d.; Lima, J.d.; Figueiras, M.; Medeiros, L.; Santos, S.d.; Gavazza, S. Influência do descarte das primeiras águas de chuva sobre a qualidade da água encaminhada às cisternas. In Proceedings of the 8th Simpósio Brasileiro de Captação e Manejo de Água de Chuva, Campina Grande, PB, Brazil, 21 August 2012.

55. Ntale, H.K.; Moses, N. Improving quality of harvested rainwater by using first flush interceptors/retainers. In Proceedings of the 11th International Conference on Rainwater Catchment Systems, Texcoco, Mexico, 25-29 August 2003.

56. Xavier, R.P. Influência de Barreiras Sanitárias na Qualidade da Água de Chuva Armazenada em Cisternas no Semiárido Paraibano; Dissertação (Mestrado em Engenharia Civil e Ambiental)-Universidade Federal de Campina Grande: Campina Grande, Brazil, 2010.

57. Lee, J.Y.; Bak, G.; Han, M. Quality of roof-harvested rainwater-comparison of different roofing materials. Environ. Pollut. 2012, 162, 422-429.

58. Oyanedel-Craver, V.A.; Smith, J.A. Sustainable colloidal-silver-impregnated ceramic filter for point-of-use water treatment. Environ. Sci. Technol. 2007, 42, 927-933.

59. Mwabi, J.; Adeyemo, F.; Mahlangu, T.; Mamba, B.; Brouckaert, B.; Swartz, C.; Offringa, G.; MpenyanaMonyatsi, L.; Momba, M. Household water treatment systems: A solution to the production of safe drinking water by the low-income communities of southern africa. Phys. Chem. Earth Parts A/B/C 2011, 36, 1120-1128.

60. Simonis, J.; Basson, A. Manufacturing a low-cost ceramic water filter and filter system for the elimination of common pathogenic bacteria. Phys. Chem. Earth Parts A/B/C 2012, 50, 269-276.

(C) 2018 by the authors. Licensee MDPI, Basel, Switzerland. This article is an open access article distributed under the terms and conditions of the Creative Commons Attribution (CC BY) license (http://creativecommons.org/licenses/by/4.0/). 